\title{
Effect of Different Extraction Methods on Stablity of Anthocyanins Extracted from Red Onion peels (Allium cepa) and Its Uses as Food Colorants
}

\author{
Om-Hashem, A. A. Ali ${ }^{2}$; Hanan, M.A.Al-sayed ${ }^{1}$; Nessrien, \\ M.N.Yasin ${ }^{1}$ and Effat, A.A. Afifi ${ }^{2}$
}

1- Food Science Dept., Fac. of Agriculture, Ain Shams Univ., Cairo, Egypt.

2- Food health Dept., National Nutrition Institute, Cairo, Egypt.

\section{ABSTRACT}

7 he present work was carried out to produce a natural red color (anthocyanins) from red onion peels (Allium cepa) by four different solvent for coloring some food product. The results showed that acidified ethanol $(0.01 \% \mathrm{Hcl})$ had the greatest efficient in extracting red onion peels anthocyanins followed by acidified methanol $(0.01 \% \mathrm{Hcl})$, while acidified distilled water (0.01\%) and distilled water are the less effective. At low pH(2.0 and3.0),natural anthocyanins extracts exhibited their greatest stabilities. Red onion peels anthocyanins extracts by acidified methanol was heated for $30 \mathrm{~min}$ at temperatures of 40, 60, 80 and $100^{\circ} \mathrm{c}$ retained 99.16, 98.79, 91.56 and 69.45 $\%$, respectively. The highest stability of anthocyanins extracted by both of acidified methanol and ethanol was at 40 to $80^{\circ} \mathrm{C}$ until holding time reached to 60 min. Color and overall acceptability of hard candy containing $0.3 \%$ natural anthocyanins extracted from red onion peels by acidified methanol recorder highly score with synthetic color (Allure).On the other hand, glazing jelly containing $0.25 \%$ natural anthocyanins extracted from red onion peels by all solvents recorded closely score with synthetic color.

Keywords: Onion peels; Natural color; Anthocyanins; Extraction; Stability; Uses. 


\section{INTRODUCTION}

$$
\begin{aligned}
& \text { Waste prevention, } \\
& \text { minimization and valorization } \\
& \text { are widely recognized as more } \\
& \text { desirable solution for waste } \\
& \text { management than "end of pipe" } \\
& \text { treatment. Large quantities of } \\
& \text { both liquid and solid wastes are } \\
& \text { produced annually by the food } \\
& \text { processing industry. There } \\
& \text { wastes materials contain } \\
& \text { principally biodegradable } \\
& \text { organic matter and their disposal } \\
& \text { creates serious environmental } \\
& \text { problems (Ayala-Zavala et al., }
\end{aligned}
$$
2011). The main phytochemical compounds present in fruits and vegetables are flavonoids, anthocyanins, vitamins $\mathrm{C}$ and $\mathrm{E}$, phenolic compounds, dietary fibers and carotenoids (González-Agiular et al., 2008). Wastes utilization from food processing industries is highly indispensable and challenging task all around the globe; numerous researchers have worked on food ingredients like natural colors, an attempt to collate the work done on the waste treatment from fruits, vegetables and cereals (Shalini et al., 2015).
Red onions, (Allium cepa $L$. ) contain anthocyanins and colorless phenolics in dried outer skins and the epidermal layer of their fleshy scales. That the major pigment in red onions was cyaniding3-glucoside, with lesser amounts of cyaniding 3laminaribioside and other minor unidentified cyaniding, peonidin and pelargonidin glucosides that showed by Robinson and Robinson (1932); Bradwein, (1965) ; Fuleki ,(1969;1971) and Du et al., (1974). However, the exploration of onion anthocyanin as food coloring properties is promising (Guinot et al., 2007).

The outer dry layers on onion bulbs, which are not edible and removed before processing have been shown to contain a wide spectrum of polyphenolic components so, the aim of many researches to produce high added - value preparations that could be used in the food industry both as alternatives to synthetic antioxidants , colorants and functional ingredients with potent beneficial bioactivities. 
To the extract the substances retried are proven generally safe and could effectives replace synthetic analogues, the results may be directly applicable to the development of morel food commodities whose consumption will contribute towards a healthier lifestyle as mentioned by Khiari et al., (2008).

Anthocyanins, as natural colorants, are widely used in the food industry as an alternative to synthetic colorants, e.g., they can replace FD\&C red No. 40 (Allure red). They are characterized a wide spectrum of color tones, ranging from orange through red, to purple and blue depending on the molecular structure and $\mathrm{pH}$ value (Dorota and Janusz ,2007). In recent years, the interest in using anthocyanins as natural alternative to synthetic food colorings is constantly increasing. In addition to their coloring efficiency, increasing evidence suggests that anthocyanins are not only nontoxicant mutagenic, but also have a wide range of therapeutic properties, (Tatiana et al., 2012).

The interest of anthocyanis derives not only from their coloring effect but also from their beneficial properties, including ant oxidizing activity, improvement in the tightness of capillary blood vessels and prevention of thrombosis aggregation, all of which reduce the risk of circulatory disease (Gluslt and Wrolstad, 2003).

Colored raisins resembling arrange of different fruits may be used to enhance the appearance of baked goods, breads, snacks, dairy desserts and other products (Pszezola, 2002). Synthetic colors are responsible for various complications such as asthma, urticaria, abortion, hyperactivity of children, carcinogenicity, decreased IQ of children, anaphylactic reactions, idiosyncrasy, sleeping disorders, hypertension, weakening of the immune system, decreased WBC and lymphocyte count and vitamin B6 deficiency (Geoffrey and Felix, 1991; Hinton, 2000). 
The increasing use of natural food colorants with the confectionary industry is discussed .Individual aspects include : reasons for using natural colorants in confectionery ; green, yellow and orange colorants pink, red and purple colorants ; blue food colorants; choosing the right color for different confectionery products (gums and Jellies ,sugar coated confectionery , foam products, hard boiled candy , fat-based coating )and health benefits associated with certain natural colorants, antioxidant activities, possible protection against cardiovascular disease and cancer (Nielsen,1999).

So, the aim of this study was to extract and determine the natural anthocyanins from red onion peels (Allium cepa) and also, to study the effect of $\mathrm{pH}$, temperature and time on their stability and utilizing them in some confectionery products, i.e. hard candy and glazing jelly.

\section{MATERIALS \& METHODS} Materials
Red onion peels (Allium cepa) was purchased from local stores at Cairo during the season of 2014/2015. All solvents used in analysis were of HPLC grad, from GFS chemicals Co. (USA).Synthetic food color (Allure) and flavoring oil were from Kamina Co. for food products, Cairo, Egypt. Corn syrup obtained from Egyptian Starch and Glucose Manufacture Co. for food products, Cairo, Egypt. Carragenan and $\mathrm{Hcl}$ were obtained from Sigma Chemicals Co., USA. Sorbic acid, calcium chloride, potassium sorbate, sucrose; citric acid was used for analysis obtained from El Gomhouria Co Cairo, Egypt.

\section{Methods}

\section{Preparation of red onion peels}

Red onion peels were cleaned from impurities and washed with tap water and dried in air oven(Carbolite) at $45^{\circ} \mathrm{C}$ for 24 hours ,then crushed into powder prior to analysis using Broun blender according to (Velickovska et al., 2013)

\section{Extraction of anthocyanins} colorant from red onion peels 
Anthocyanins were extracted from red onion peels according to Rodriguez-Saona and Wrolstad, (2001).Ten gram of ground red onion peels soaked overnight at $4^{\circ} \mathrm{C}$ in solvent using different extraction solvents :(1) acidified methanol (0.01\% Hcl 37\%); (2) acidified ethanol $(0.01 \%$ Hcl $37 \%)$;(3) acidified distilled water $(0.01 \%$ $\mathrm{Hcl} 37 \%$ ), and(4) distilled water. The anthocyanins extract was filtrate through filter paper Whatman No.1 into conical flask. The extraction and filtration continued till the residue was colorless. The anthocyanins extract was concentrated by rotary vacuum evaporator at $40{ }^{\circ} \mathrm{C}$.

\section{Determination of total anthocyanins}

The filtered anthocyanin extract was diluted with the extracting solvent measured at $520 \mathrm{~nm}$. The total anthocyanin was calculated using equation descried by Du and Francis, (1973).

Total anthocyanins $\mathrm{mg} / 100 \mathrm{~g}=$ Absorbance X dilution factor/ Sample weight $\mathrm{X}$ Extinction coefficient*
*: (26900 molar in $\mathrm{L} \mathrm{X} \mathrm{mol}^{-1} \mathrm{X} \mathrm{cm}^{-1}$. for cyaniding -3-glucoside).

One gram of anthocyanin was absorption to $1 \mathrm{gm}$ of solid matrix (anhydrase dextrin) and dried in oven at $40^{\circ} \mathrm{C}$ for 24 hours according to Rizk et al., (2009).

\section{Anthocyanin stability Effect of $\mathrm{pH}$}

Effect of different $\mathrm{pH}$ values on anthocyanin retention was measured according to the method described by Elbe and Huang, (1974), one $\mathrm{ml}$ of extracted anthocyanins solution was mixed with4 $\mathrm{ml}$ of Mcllvaines buffer of various range from 2.0 to 9.0 at $4^{\circ} \mathrm{C}$ and absorbance readings were measured using spectrophotometer at $520 \mathrm{~nm}$.

\section{Effect of temperature}

Effect of temperature on anthocyanins retention was measured according to Saguy (1979) with some modifications. $1 \mathrm{ml}$ of extracted anthocyanins solution and $9 \mathrm{ml}$ of optimum buffer solution to adjusted $\mathrm{pH} 2.0$ were pleased in a 
thermostatically controlled water bath at different temperatures $\left(40,60,80\right.$ and $\left.100^{\circ} \mathrm{C}\right)$ for $30 \mathrm{~min}$. The samples were further cooled down immediately in an ice water bath and absorbance measurements were read by spectrophotometer at $520 \mathrm{~nm}$.

\section{Thermal stability}

Anthocyanins solution was hold at $\mathrm{pH}$ value 2.0 for 30 , 60, 90 and $120 \mathrm{~min}$ at 40,60, 80 and $100^{\circ} \mathrm{Cin}$ water bath then cooled immediately in an ice water bath and measuring absorbance of solution by spectrophotometer at $520 \mathrm{~nm}$.

\section{Applications}

\section{Hard candy Processing:}

Hard candy was manufactured in the laboratory using the procedure as described by Staniec (1994).The formulation of control sample was shown in Table (1).

\section{Procedures in steps:}

- Water, sucrose, corn syrup and citric acid were mixed together and heated to reach $157.5^{\circ} \mathrm{C}$ with continuous stirring and then the mixture was cooled to reach $110^{\circ} \mathrm{C}$.

- Synthetic red color (Allure) was added at 9.5 $\mathrm{mg} / 100 \mathrm{~g}$ of whereas natural anthocyanins extracted from red onion peels were added at 0.15 , $0.20, \quad 0.25 \quad$ and $0.30 \mathrm{mg} / 100 \mathrm{~g}$ of mixture.

- Flavoring agent was added to the formula, and then formulated and cooled to reach room temperature and then packed.

\section{Glazing jelly processing:}

Glazing jelly prepared in the laboratory using the ingredients which were given in table (1) according to Gad Allah et al., (2002).

\section{Procedures in steps:}

- A mixture of sucrose and carragenan was boiled first in the water then calcium chloride, sorbic acid and potassium sorbate were added to the mixture.

- Corn syrup was added continuous stirring. 
- After complete dissolving of the ingredients the heating was stopped.

- A synthetic color (Allure) was used at $9.5 \mathrm{mg} / 100 \mathrm{~g}$ of the mixture whereas natural anthocyanin extracted from red onion peels were added at 0.20 , 0.25 and $0.30 \mathrm{mg} / 100 \mathrm{gm}$ of the mixture.

- Flavoring agent was added.

- Glazing jelly samples were cooled in the refrigerator for $5 \mathrm{~h}$.

\section{Sensory evaluation}

Samples of hard candy and glazing jelly were subjected to sensory evaluation by ten panelists from National Nutrition Institute (NNI). Panelists were asked to evaluate color, clarity, flavor, texture, grainess and overall acceptability of the glazing jelly and color, flavor, texture, clarity, mouth feel and overall acceptability of the hard candy processed according to the method described by Reitmeler and Nonnecke (1991).

\section{Statistical analysis:}

Analysis of variance and Duncan's multiple range test was carried out according to Statistical Analysis System SAS, (2006) at the computer center, Faculty of Agriculture, Ain shams University.

\section{RESULTS \& DISCUSSION}

\section{Total anthocyanins}

Ethanol acidified with $\mathrm{HCl} 0.01 \%$, methanol acidified with $\mathrm{HCl} 0.01 \%$, distilled water and distilled water acidified with $\mathrm{HCl} 0.01 \%$ were used in extracting anthocyanin from red onion peels . Total anthocyanins extracted with the different solvents are shown in Figure (1). Addition of acids to methanol and ethanol increased the efficient of anthocyanins extraction compared with the distilled water and acidified distilled water. In general ,the results indicated that ethanol acidified with $\mathrm{HCl}$ showed the strongest influence on amount of extracted anthocyanins followed 
by methanol acidified with $\mathrm{Hcl}$ and then distilled water. These results are similar to the results recorded by Selim et al., (2008) and Mattuk, (1998).

The effect of different $\mathrm{pH}$ values on retention $\%$ of anthocyanins extracted from red onion peels by different solvents was presented in Table (2). Results showed that the retention $\%$ of anthocyanins extracted from red onion peels by different solvents was found to increase with elevating the $\mathrm{pH}$ values. Significant differences were observed between different $\mathrm{pH}$ values. Generally, increasing the $\mathrm{pH}$ value from 2.0 to 7.0 the anthocyanins instilling were gradually increased it means that anthocyanins were more stable at acidic $\mathrm{pH}$ values. The maximum retention (\%) of anthocyanins found at $\mathrm{pH} 2.0$ to extraction with acidified methanol (99.17\%) followed by acidified ethanol (96.55\%), then acidified distilled water $(95.25 \%)$ and distilled water $(94.76 \%)$. On the other hand, the same anthocyanins may present different trends due to $\mathrm{pH}$ variation such as neutral solutions decreased the retention rate of anthocyanins, on contrary ,alkaline solution increased the retention. These results agree with Revilla et al., (1998); Heredia et al., (1998) and Gauche et al., (2010).

The effect of different thermal treatments on retention rate (\%) (Based on absorbance values measured for anthocyanins extracts before and after heat treatments) of anthocyanins extracted from red onion peels by methanol acidified by $\mathrm{Hcl}$, ethanol acidified by $\mathrm{Hcl}$, distilled water acidified by $\mathrm{Hcl}$ and distilled water was illustration Table (3). The results showed that the anthocyanins degradation significantly $(\mathrm{P}>0.05)$ increased when the treatment temperature was increased from 40 to $100^{\circ} \mathrm{C}$ $/ 30 \mathrm{~min}$ at $\mathrm{pH}$ 2.0. Prolonged exposure of natural anthocyanins colors at moderate temperature ranged between 40 and $60^{\circ} \mathrm{C}$. Showed similar stability were observed whereas at above $60^{\circ} \mathrm{C}$, the degradation in anthocyanins color extracted by all used 
solvents increased gradually by increasing temperature. The highest retention rate was (99.16\%)at $40^{\circ} \mathrm{C} / 30 \mathrm{~min}$. for anthocyanin extracted from red onion peels by methanol acidified $\mathrm{Hcl}$ followed by (99.15\%) and (99.11\%) for anthocyanins extracted from red onion peels by ethanol acidified by $\mathrm{Hcl}$ and distilled water acidified by $\mathrm{Hcl}$. This results were agree with Laleh et al.,(2006); Selim et al.,(2008) , Rizk et al., (2009) and Sharif et al., (2010) .

The thermal stability of anthocyanins color extracted from red onion peels by different solvents on duration time at various temperatures ranged between 40 and $100^{\circ} \mathrm{C}$ are presented in Tables (4 to7). Results indicated that, the increase of destruction occurred by increasing the duration time and temperatures for all natural anthocyanins color extracted from red onion peels by all used solvents, On the other hand, the retention of natural anthocyanins color extracted from red onion peels by methanol acidified by
$\mathrm{Hcl}$, ethanol acidified by $\mathrm{Hcl}$, distilled water acidified by $\mathrm{Hcl}$ and distilled water being 45.67 , $39.47,31.17$ and $30.66 \%$ after holding time for $120 \mathrm{~min}$ at $100^{\circ} \mathrm{C}$, respectively. The highest retention of anthocyanins observed at 40 and $60^{\circ} \mathrm{C}$ unit holding time reached to $120 \mathrm{~min}$. for all used solvent compared to other thermal treatments. The highest stability anthocyanins extracted by both of acidified methanol and acidified ethanol was at 40 to $80^{\circ} \mathrm{Cuntil}$ holding time reached to $60 \mathrm{~min}$. These results agree with Mohamed $\boldsymbol{e t}$ al., (2006); Santos et al., (2012). Markakis, (1982) suggested that, stability of anthocyanins pigments has been influenced by enzymes, $\mathrm{pH}$, temperatures, oxygen, light and metals. It could conclude that, the degradation of red onion peels anthocyanins greatly influenced by temperature and holding time. Finally it could be noticed that anthocyanins extracted by both of acidified methanol and ethanol showed higher thermal stability at different temperatures that are 
required for several processing of different products.

\section{Applications Hard candy}

Sensory attributes of hard candy prepared with different levels of anthocyanins extracted from red onion peels by different solvents (acidified methanol , acidified ethanol acidified distilled water and distilled water) were statistically analyzed and results are given in Table (8) and Fig.(2).No significant difference was observed in flavor, texture, clarity and mouth feel of hard candy prepared with different levels of anthocyanins extracted from red onion peels by different solvents and synthetic color. On the other hand, color and overall acceptability of hard candy prepared with $0.3 \%$ natural anthocyanins extracted from red onion peels by acidified methanol and ethanol recorded highly score with synthetic color while, color and overall acceptability of hard candy prepared with 0.2 and $0.25 \%$ natural anthocyanins extracted from red onion peels by acidified and non-acidified distilled water recorder closely scores with synthetic color.

\section{Glazing jelly}

Sensory attributes of glazing jelly prepared with different levels of anthocyanins extracted from red onion peel by different solvents (acidified methanol, acidified ethanol, acidified distilled water and distilled water) were statistically analyzed and the results are given in Table(9)and Fig.(3).No significance difference was observed in texture and grainess while slightly significant difference was observed in flavor and clarity of glazing jelly samples were prepared with all levels of anthocynins were extracted from red onion peels by different solvents and synthetic color. Color and overall acceptability of glazing jelly prepared with $0.25 \%$ natural anthocyanins extracted from red onion peel by all solvents recorded closely score with synthetic color. 


\section{CONCLUSION}

Natural anthocyanins color play very important role in determining the acceptability food for consumer. Furthermore, anthocyanins are very important in human nutrition and food colorants. The most important outcome of this study regarding the optimization of conventional anthocyanins extraction from Egyptian red onion peels, that appear as promising source of water soluble pigments (anthocyanins).For instant, to develop a sustainable process, extracts were obtained utilizing cheap solvents such as extraction by acidified ethanol was more efficient than other systems regarding the extraction yield of total anthocyanins. The highest stability anthocyanins extracted by both of acidified methanol and acidified ethanol was at 40 to $80^{\circ} \mathrm{Cuntil}$ holding time reached to $60 \mathrm{~min}$, it could be noticed that anthocyanins extracted by both of acidified methanol and ethanol showed higher thermal stability at different temperatures that are required for several processing of different products. In addition, hard candy containing $0.3 \%$ natural anthocyanins extracted by acidified methanol and acidified ethanol, and glazing jelly containing $0.25 \%$ of natural anthocyanins extracted by the same solvents were given the highest score of color and overall acceptability similar with synthetic color. In general, consumer preparation has been that natural food colorant ingredient would be safer, healthful and considered as potential food colorants for preparing hard candy and glazing jelly.

\section{REFERENCES}

\section{Ayala-Zavala JF; Vega-Vega \\ V; Rosas-Dom'ınguez C \\ (2011):}

Agro-industrial potential of exotic fruit byproducts as a source of food additives. Food Research Inter, 44 (7): 1866-1874.

\section{Bradwein BJ (1965):}

The pigments in three cultivars of the common 
onion (Allium Cepa). J.

Food Sci., 30:680-685.

\section{Dorota WT and Janusz C} (2007):

Color changes of a preparation from red cabbage during storage in a model system. Food Chem.,104:709-714.

\section{Du CT; Wang PL and Francis} FJ (1974):

Cyanidin 3Iaminaribioside in spanish red onion (Allium Cepa L.). J. Food Sci., 39:1265-1266.

Du CT and Francis FJ (1973):

Anthocyanins of roselle (Hibiscus Sabdariffa, L.). J. Food Sci., 38:810-812.

Elbe HV and Huang AA (1974):

Stability comparison of two beta cyanine pigments- amaranthin and betanine. $\mathrm{J}$ Food Sci., 5: 670-674.

Fuleki T (1969):
The anthocyanins of strawberry, rhubarb, adish and onion. J. Food Sci., 34:365-369.

Fuleki T (1971):

Anthocyanin in red onion Allium Cepa . J. Food Sci., 36:101-104.

Gad Allah ME; Rezk I.RS; Ebeid HM and Manar TI (2002):

Studies on some natural colorants and their utilizations in foodstuff. Msc.thesis, Fac.of Aric. Ain Shams Univ.Cairo,Egypt.

Gauche C; Malagoli ES and Luiz MTB (2010):

Effect of $\mathrm{pH}$ on the co pigmentation of anthocyanins from Cabernet Sauvign on grape extracts with organic acids. Sci. Agric. (Piracicaba, Braz.)., 67(1):.41-46.

Geoffrey B A and Felix MB (1991): 
Canthaxanthin and the eye:A critical ocular toxicologic assessment. Cut Ocular Toxicol., 10: 115-155.

Gluslt $M$ and Wrolstad R(2003):

Acylated anthocyanin from edible sucrose and their application in food system. Bio chem. Eng. J., 14: 217-225.

González-Aguilar G; RoblesSánchez RM; Martínez- Téllez MA; Olivas GI; AlvarezParrilla, E and De La Rosa LA (2008):

Bioactive compounds in fruits: health benefits and effect of storage conditions. Stewart Postharvest Review, 4 (3):1-10.

Guinot P; Benonge L; Nicolet G; Gargadennec A; Andary C and Rapiot S (2007):

Combined dyeing and antioxidative properties of some plant by products. Avta Bot. Gal., 154:43-52

Heredia FJ; Francia-Aricha EM; Rivas-Gonzalo JC; Vicario IM and Santos-Buelga C (1998):

Chromatic

characterization of anthocyanins from red grapes - I. PH effect. Food Chem., 63: 491498.

Hinton DM (2000):

US FDA "Redbook II" immunotoxicity testing guidelines and research in immunotoxicity evaluations of food chemicals and new food proteins. Toxicol. Pathol, 28: 467-478.

\section{Khiari Z; Makris DP and} Kefalas P(2008):

Recovery of bioactive flavonols from onion solid wastes employing water/ethanol-based solvent Systems. Food Sci. and Tech. 4: 497502. 
Laleh GH; Frydoonfar H; Heidary R; Jameei R and Zare S (2006):

The effect of light, temperature, $\mathrm{pH}$ and species on stability of anthocyanin pigments in four Berberi species.Pakistan $\mathrm{J}$. Nutrition, 5 (1): 90-92.

Markakis P (1982):

Stability of anthocyanins in foods .In anthocyanins as food colors; Makakis, P. , Ed; Academic Press: New York , pp. 163-180.

Mattuk HI (1998):

Studies on the utilization of natural colourants extractrd from some plant sousrec .Egypt J. Food Chem. ,13:286303.

\section{Mohammed A; Reza H and} Rashid J (2006):

The effects of heating, $\mathrm{UV}$ irradiation and $\mathrm{pH}$ on stability of Sahesardasht
Grape anthocyanin - co pigment complex.

Nielsen SR (1999):

Natural colors for confectionery . Food Markiting \& Tech.,13(3):6,8-9.

Pszezola DE (2002):

Finding new ways to help enhance appearance and texture of foods. Food Tech.,56(11):3854.

Reitmeler CA and Nonnecke GR (1991):

Objective and sensory evaluation of fresh fruit of day neutral strawberry cultivars .J. Hort. Sci. , 26:843-845.

Revilla E; Ryan J M and Martin-Ortega G (1998):

Comparison of several procedures used for the extraction of anthocyanins from red grapes. J. Agric. Food Chem., 46:4592-4597. 
Rizk EM; Azouz A and Hareedy LAM (2009):

Evaluation of red Cabbage Anthocyanin Pigments and Potential Uses as Antioxidant and Natural Food Colorants. J. Agric. Sci. Ain Shams Univ. Cairo .,17(2):361-372.

\section{Robinson GM and Robinson R} (1932):

A surve of anthocyanins. Bio-chem. J., 26:1647-1664.

Rodriguez-Saona LE and Wrolstad R E (2001):

Current protocols in food analytical chemistry F1.1.1F1.1.11.

Saguy I (1979):

Thermal kiniteic degradation of betanin and betalamic acid. J. Agric. Food Chem. ,26:197-199.

Santos DT; Veggi PC; Angela $M$ and Meireles A (2012):

Optimization and economic evaluation of pressurized liquid extraction of phenolic compounds from Jabuticaba skins. J. Food Eng.,108 : 444452.

S.A.S. (2006):

Statistical Analysis System. SAS Inistute, Cary. NC .27518-800U.S.A.

Selim KA; Khalil KE; Abdel Bary MS and Abdel- Azeiim NA (2008):

Extraction, encapsulation and utilization of red pigments from roselle (Hibiscus Sabdariffa L.) as natural food colorants Special Volume Conference, Mar. Alex. J. Food. Sci. \& Tech. PP.7-20.

\section{Shalini GR; Jyoti N; Neetu} JNand Charanjit K (2015):

Food industry waste: mine of nutraceuticals. Int. J.Sci., Env. and Tech., 4(1): 205 - 229. 
Effect of Different Extraction Methods on Stablity of Anthocyanins Extracted from Red Onion peels (Allium cepa) and Its Uses as Food Colorants

Om-Hashem, A. A. Ali; Hanan, M.A.Al-sayed; Nessrien, M.N.Yasin and Effat, A.A. Afifi

Sharif A; Saim N; Jasmani H and Ahmed WYW (2010):

Effect of solvent and temperature on the extraction of colorant from onion (Allium cepa ) skin using pressurized liquid extractio.Asia J. Applied,3(4):262- 268.

Staniec N (1994):

Acesulfame $-\mathrm{K}$

Guarantees Solubility, Stability of Sweets .Candy Industry,(16).

\section{Tatiana L; Brenner-Weiss G;} Franzreb $M$ and Nusser $M$ (2012):

Recovery of anthocyanins from grape pomace extract
(Pinot Noir) using magnetic particles based on poly (Vinyl Alcohol). Cellulose Chem. And Tech.,46 (7-8): 427-433.

\section{Velickovska S K; Mirhosseini} H and Bogenva E (2013): Isolation of anthocyanins by high-speed countercurrent chromatography and application of the color activity concept to different varieties of red grape pomace from macedonia. J. Nutr. Food sci., 3(6):3-7. 
Effect of Different Extraction Methods on Stablity of Anthocyanins Extracted from Red Onion peels (Allium cepa) and Its Uses as Food Colorants

Om-Hashem, A. A. Ali; Hanan, M.A.Al-sayed; Nessrien, M.N.Yasin and Effat, A.A. Afifi

Table (1): Basic formulation of hard candy and glazing jelly samples

\begin{tabular}{|c|c|c|c|}
\hline \multicolumn{2}{|c|}{ Hard candy } & \multicolumn{2}{c|}{ Glazing jelly } \\
\hline Ingredients & $\mathbf{( \% )}$ & Ingredients & $\mathbf{( \% )}$ \\
\hline Sucrose & 48.48 & Sucrose & 35.85 \\
\hline Corn syrup & 25.90 & Water & 54.35 \\
\hline Water & 25.26 & Corn syrup & 9.06 \\
\hline Flavoring oil & 0.21 & Carragenan & 0.38 \\
\hline Citric acid & 0.15 & Sorbic acid & 0.08 \\
\hline & & Potassium sorbate & 0.13 \\
\hline & & Calcium chloride & 0.15 \\
\hline
\end{tabular}

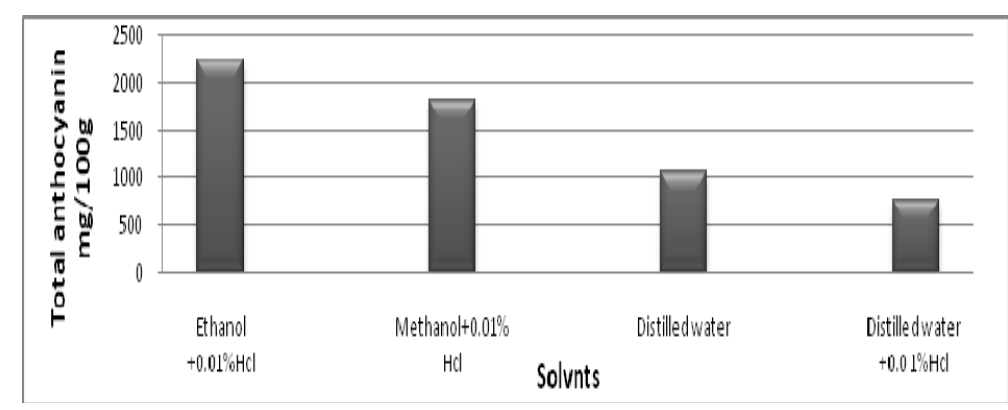

Fig (1): Total anthocyanins extracted from onion peels by different solvents

Table (2): Effect of $\mathrm{pH}$ values on retention rate of anthocyanins extracted from red onion peels by different solvents

\begin{tabular}{|c|c|c|c|c|}
\hline \multirow{2}{*}{ pH values } & \multicolumn{4}{|c|}{ Acidified } \\
\cline { 2 - 5 } & \multicolumn{3}{|c|}{$\begin{array}{c}\text { Distilled } \\
\text { water }\end{array}$} \\
\cline { 2 - 5 } & Methanol & Ethanol & $\begin{array}{c}\text { Distilled } \\
\text { water }\end{array}$ & \\
\hline $\mathbf{2}$ & $99.17^{\mathrm{a}}$ & $96.55^{\mathrm{a}}$ & $95.25^{\mathrm{a}}$ & $94.76^{\mathrm{a}}$ \\
\hline $\mathbf{3}$ & $96.64^{\mathrm{b}}$ & $95.65^{\mathrm{ab}}$ & $94.16^{\mathrm{ab}}$ & $92.83^{\mathrm{ab}}$ \\
\hline $\mathbf{4}$ & $90.53^{\mathrm{cb}}$ & $88.81^{\mathrm{b}}$ & $87.47^{\mathrm{b}}$ & $84.57^{\mathrm{b}}$ \\
\hline $\mathbf{5}$ & $84.22^{\mathrm{c}}$ & $78.92^{\mathrm{c}}$ & $77.41^{\mathrm{c}}$ & $72.05^{\mathrm{c}}$ \\
\hline $\mathbf{6}$ & $73.40^{\mathrm{e}}$ & $70.56^{\mathrm{e}}$ & $65.00^{\mathrm{e}}$ & $64.38^{\mathrm{d}}$ \\
\hline $\mathbf{7}$ & $69.28^{\mathrm{f}}$ & $63.37^{\mathrm{f}}$ & $56.26^{\mathrm{f}}$ & $51.88^{\mathrm{e}}$ \\
\hline $\mathbf{8}$ & $78.98^{\mathrm{d}}$ & $71.94^{\mathrm{e}}$ & $68.20^{\mathrm{de}}$ & $59.79^{\mathrm{d}}$ \\
\hline $\mathbf{9}$ & $83.04^{\mathrm{c}}$ & $75.57^{\mathrm{d}}$ & $71.83^{\mathrm{d}}$ & $61.96^{\mathrm{d}}$ \\
\hline
\end{tabular}

Means in a raw showing the same letter are not significantly different $(\mathrm{P} \geq 0.05)$ 
Effect of Different Extraction Methods on Stablity of Anthocyanins Extracted from Red

Onion peels (Allium cepa) and Its Uses as Food Colorants

Om-Hashem, A. A. Ali; Hanan, M.A.Al-sayed; Nessrien, M.N.Yasin and Effat, A.A. Afifi

Table (3): Effect of temperature on the retention rate of anthocyanins extracted from onion peel by different solvents

\begin{tabular}{|c|c|c|c|c|}
\hline \multirow{2}{*}{ Treatments } & \multicolumn{4}{|c|}{ Retention (\%) } \\
\cline { 2 - 5 } & $\mathbf{4 0}^{\circ} \mathbf{c}$ & $\mathbf{6 0}^{\circ} \mathbf{c}$ & $\mathbf{8 0}^{\circ} \mathbf{c}$ & $\mathbf{1 0 0}^{\circ} \mathbf{c}$ \\
\hline Methanol Hcl & $99.16^{\mathrm{Aa}}$ & $98.79^{\mathrm{Aa}}$ & $91.56^{\mathrm{Ab}}$ & $69.45^{\mathrm{Ac}}$ \\
\hline Ethanol Hcl & $99.15^{\mathrm{Aa}}$ & $98.01^{\mathrm{Aa}}$ & $86.68^{\mathrm{Bb}}$ & $66.22^{\mathrm{Bc}}$ \\
\hline Distilled water Hcl & $99.11^{\mathrm{Aa}}$ & $95.49^{\mathrm{Ba}}$ & $85.83^{\mathrm{Bb}}$ & $60.92^{\mathrm{Cc}}$ \\
\hline Distilled water & $98.62^{\mathrm{Aa}}$ & $94.91^{\mathrm{Ba}}$ & $79.63^{\mathrm{Cb}}$ & $55.80^{\mathrm{Dc}}$ \\
\hline
\end{tabular}

Means values in same column showed the same superscript capital letters are not significantly different $(\mathrm{P} \geq 0.05)$

Means values in same raw showed the same superscript small letters are not significantly different $(\mathrm{P} \geq 0.05)$

Table (4 ): Thermal stability of anthocyanin extracted by methanol HCl from onion peels with different temperatures and times

\begin{tabular}{|c|c|c|c|c|c|}
\hline \multirow[t]{2}{*}{ Treatments } & \multirow[t]{2}{*}{ Temperatures } & \multicolumn{4}{|c|}{ Retention (\%) } \\
\hline & & 30min & 60min & $90 \mathrm{~min}$ & $120 \mathrm{~min}$ \\
\hline \multirow{4}{*}{$\begin{array}{l}\text { Methanol } \\
0.01 \% \text { Hcl }\end{array}$} & $40 \circ c$ & $99.16^{\mathrm{Aa}}$ & $98.83^{\mathrm{Aa}}$ & $97.20^{\mathrm{Ab}}$ & $96.50^{\mathrm{Ab}}$ \\
\hline & $60 \circ \mathrm{c}$ & $98.79^{\mathrm{Aa}}$ & $96.56^{\mathrm{Aab}}$ & $92.14^{\mathrm{Abc}}$ & $89.33^{\mathrm{Bc}}$ \\
\hline & $80 \circ \mathrm{c}$ & $91.56^{\mathrm{Ba}}$ & $86.56^{\mathrm{Bab}}$ & $82.59^{\mathrm{Bbc}}$ & $78.79^{\mathrm{Cc}}$ \\
\hline & $100 \circ \mathrm{c}$ & $69.45^{\mathrm{Ca}}$ & $64.19^{\mathrm{Cb}}$ & $54.83^{\mathrm{Cc}}$ & $45.67^{\mathrm{Dd}}$ \\
\hline
\end{tabular}

Means values in same column showed the same superscript capital letters are not significantly different $(\mathrm{P} \geq 0.05)$

Means values in same raw showed the same superscript small letters are not significantly different $(\mathrm{P} \geq 0.05)$

Table (5): Thermal stability of anthocyanin extracted by ethanol Hcl from onion peels with different temperatures and times

\begin{tabular}{|c|c|c|c|c|c|}
\hline \multirow{2}{*}{$\begin{array}{c}\text { Treatment } \\
\text { s }\end{array}$} & \multirow{2}{*}{$\begin{array}{c}\text { Temperatur } \\
\text { es }\end{array}$} & \multicolumn{4}{|c|}{ Retention (\%) } \\
\hline & & 30min & $60 \mathrm{~min}$ & $90 \mathrm{~min}$ & $120 \mathrm{~min}$ \\
\hline \multirow{4}{*}{$\begin{array}{c}\text { Ethanol } \\
0.01 \% \text { Hcl }\end{array}$} & $40 \circ \mathrm{c}$ & $99.15^{\mathrm{Aa}}$ & $98.63^{\mathrm{Aa}}$ & $96.74^{\mathrm{Aa}}$ & $93.80^{\mathrm{Aa}}$ \\
\hline & $60 \circ \mathrm{c}$ & $98.01^{\mathrm{Aa}}$ & $95.15^{\mathrm{Aab}}$ & $89.96^{\mathrm{Abc}}$ & $87.25^{\mathrm{Ac}}$ \\
\hline & $80 \circ \mathrm{c}$ & $86.68^{\mathrm{Ba}}$ & $81.94^{\mathrm{Ba}}$ & $77.09^{\mathrm{Bab}}$ & $68.16^{\mathrm{Bb}}$ \\
\hline & $100 \circ \mathrm{c}$ & $66.22^{\mathrm{Ca}}$ & $56.81^{\mathrm{Cab}}$ & $42.17^{\mathrm{Cab}}$ & $39.47^{\mathrm{Cc}}$ \\
\hline
\end{tabular}

Means values in same column showed the same superscript capital letters are not significantly different $(\mathrm{P}<0.05)$

Means values in same raw showed the same superscript small letters are not significantly different $(\mathrm{P}<0.05)$ 
Effect of Different Extraction Methods on Stablity of Anthocyanins Extracted from Red Onion peels (Allium cepa) and Its Uses as Food Colorants

Om-Hashem, A. A. Ali; Hanan, M.A.Al-sayed; Nessrien, M.N.Yasin and Effat, A.A. Afifi

Table (6): Thermal stability of anthocyanin extracted by distilled water Hcl from onion peels with different temperatures and times

\begin{tabular}{|c|c|c|c|c|c|}
\hline \multirow[t]{2}{*}{ Treatments } & \multirow{2}{*}{$\begin{array}{c}\text { Temperatur } \\
\text { es }\end{array}$} & \multicolumn{4}{|c|}{ Retention (\%) } \\
\hline & & 30min & $60 \mathrm{~min}$ & $90 \mathrm{~min}$ & $120 \mathrm{~min}$ \\
\hline \multirow{4}{*}{$\begin{array}{c}\text { Distilled } \\
\text { water } \\
0.01 \% H c l\end{array}$} & $40 \circ \mathrm{c}$ & $99.11^{\mathrm{Aa}}$ & $98.57^{\mathrm{Aa}}$ & $95.87^{\mathrm{Ab}}$ & $94.84^{\mathrm{Ac}}$ \\
\hline & $60 \circ \mathrm{c}$ & $95.49^{\mathrm{Aa}}$ & $92.04^{\mathrm{Aa}}$ & $87.93^{\mathrm{Aa}}$ & $86.76^{\mathrm{Aa}}$ \\
\hline & $80 \circ c$ & $85.83^{\mathrm{Ba}}$ & $77.93^{\mathrm{Ba}}$ & $68.54^{\mathrm{Bb}}$ & $67.64^{\mathrm{Bb}}$ \\
\hline & $100 \circ \mathrm{c}$ & $60.92^{\mathrm{Ca}}$ & $44.77^{\mathrm{Cb}}$ & $40.66^{\mathrm{Cc}}$ & $31.17^{\mathrm{Cd}}$ \\
\hline
\end{tabular}

Means values in same column showed the same superscript capital letters are not significantly different $(\mathrm{P} \geq 0.05)$

Means values in same raw showed the same superscript small letters are not significantly different $(\mathrm{P} \geq 0.05)$

Table (7): Thermal stability of anthocyanin extracted by distilled water from onion peels with different temperatures and times

\begin{tabular}{|c|c|c|c|c|c|}
\hline \multirow[t]{2}{*}{ Treatments } & \multirow[t]{2}{*}{ Temperatures } & \multicolumn{4}{|c|}{ Retention (\%) } \\
\hline & & 30min & $60 \mathrm{~min}$ & $90 \mathrm{~min}$ & $120 \mathrm{~min}$ \\
\hline \multirow{4}{*}{$\begin{array}{c}\text { Distilled } \\
\text { water }\end{array}$} & $40 \circ c$ & $98.62^{\mathrm{Aa}}$ & $98.05^{\mathrm{Aa}}$ & $95.26^{\mathrm{Aab}}$ & $93.83^{\mathrm{Ab}}$ \\
\hline & $60 \circ \mathrm{c}$ & $94.91^{\mathrm{Aa}}$ & $93.78^{\text {Aab }}$ & $85.76^{\mathrm{Bbc}}$ & $83.71^{\mathrm{Bc}}$ \\
\hline & $80 \circ c$ & $79.63^{\mathrm{Ba}}$ & $66.23^{\mathrm{Bb}}$ & $53.69^{\mathrm{Cc}}$ & $49.29^{\mathrm{Cc}}$ \\
\hline & $100 \circ \mathrm{c}$ & $55.81^{\mathrm{Ca}}$ & $36.52^{\mathrm{Cb}}$ & $35.62^{\mathrm{Db}}$ & $30.66^{\mathrm{Db}}$ \\
\hline
\end{tabular}

Means values in same column showed the same superscript capital letters are not significantly different $\mathrm{P} \geq 0.05$ )

Means values in same raw showed the same superscript small letters are not significantly different $(\mathrm{P} \geq 0.05)$ 
Effect of Different Extraction Methods on Stablity of Anthocyanins Extracted from Red

Onion peels (Allium cepa) and Its Uses as Food Colorants

Om-Hashem, A. A. Ali; Hanan, M.A.Al-sayed; Nessrien, M.N.Yasin and Effat, A.A. Afifi

Table (8): Means scores of sensory properties of hard candy prepared with different levels of anthocyanin extracted from onion peels by different solvents.

\begin{tabular}{|c|c|c|c|c|c|}
\hline \multicolumn{6}{|c|}{ Means scores of sensory properties } \\
\hline \multicolumn{6}{|c|}{ Color } \\
\hline Treatment & $\begin{array}{l}\text { Synthetic } \\
\text { color }\end{array}$ & $0.15 \%$ & $0.20 \%$ & $0.25 \%$ & $0.3 \%$ \\
\hline Acidified methanol & $8.3^{\mathrm{Abc}}$ & $7.1^{\mathrm{Ad}}$ & $8.1^{\mathrm{Ac}}$ & $8.7^{\text {Aab }}$ & $9.0^{\mathrm{Aa}}$ \\
\hline Acidified ethanol & $8.3^{\mathrm{Ab}}$ & $7.3^{\mathrm{Ac}}$ & $8.5^{\mathrm{Aab}}$ & $8.6^{\mathrm{Aab}}$ & $8.9^{\mathrm{Aa}}$ \\
\hline Acidified distilled water & $8.3^{\mathrm{Aa}}$ & $7.4^{\mathrm{Ab}}$ & $7.9^{\mathrm{Aab}}$ & $8.2^{\mathrm{Aa}}$ & $8.2^{\mathrm{Ba}}$ \\
\hline Distilled water & $8.3^{\mathrm{Aa}}$ & $7.3^{\mathrm{Ab}}$ & $8.5^{\mathrm{Aa}}$ & $8.5^{\mathrm{Aa}}$ & $8.1^{\mathrm{Ba}}$ \\
\hline \multicolumn{6}{|c|}{ Flavor } \\
\hline Acidified methanol & $8.5^{\mathrm{Aa}}$ & $8.4^{\mathrm{Aa}}$ & $8.5^{\mathrm{Aa}}$ & $8.5^{\mathrm{Aa}}$ & $8.4^{\mathrm{Aa}}$ \\
\hline Acidified ethanol & $8.5^{\mathrm{Aa}}$ & $8.5^{\mathrm{Aa}}$ & $8.5^{\mathrm{Aa}}$ & $8.3^{\mathrm{Aa}}$ & $8.2^{\mathrm{Aa}}$ \\
\hline Acidified distilled water & $8.5^{\mathrm{Aa}}$ & $8.4^{\mathrm{Aa}}$ & $8.4^{\mathrm{Aa}}$ & $8.4^{\mathrm{Aa}}$ & $8.3^{\mathrm{Aa}}$ \\
\hline Distilled water & $8.5^{\mathrm{Aa}}$ & $8.5^{\mathrm{Aa}}$ & $8.5^{\mathrm{Aa}}$ & $8.5^{\mathrm{Aa}}$ & $8.4^{\mathrm{Aa}}$ \\
\hline \multicolumn{6}{|c|}{ Texture } \\
\hline Acidified methanol & $8.0^{\mathrm{Aa}}$ & $7.4^{\mathrm{Bb}}$ & $7.4^{\mathrm{Cb}}$ & $7.4^{\mathrm{Bb}}$ & $7.5^{\mathrm{Bab}}$ \\
\hline Acidified ethanol & $8.0^{\mathrm{Aa}}$ & $8.1^{\mathrm{Aa}}$ & $7.9^{\mathrm{Ba}}$ & $8.0^{\text {Aa }}$ & $8.0^{\mathrm{ABa}}$ \\
\hline Acidified distilled water & $8.0^{\mathrm{Aa}}$ & $8.4^{\mathrm{Aa}}$ & $8.4^{\mathrm{Aa}}$ & $8.3^{\mathrm{Aa}}$ & $8.4^{\mathrm{Aa}}$ \\
\hline Distilled water & $8.0^{\mathrm{Aa}}$ & $8.2^{\text {Aa }}$ & $8.0^{\mathrm{ABa}}$ & $8.0^{\mathrm{Aa}}$ & $8.1^{\mathrm{ABa}}$ \\
\hline \multicolumn{6}{|c|}{ Clarity } \\
\hline Acidified methanol & $8.5^{\mathrm{Aa}}$ & $8.4^{\mathrm{Aa}}$ & $8.6^{\mathrm{Aa}}$ & $8.6^{\mathrm{Aa}}$ & $8.6^{\text {Aa }}$ \\
\hline Acidified ethanol & $8.5^{\mathrm{Aa}}$ & $8.6^{\mathrm{Aa}}$ & $8.7^{\mathrm{Aa}}$ & $8.7^{\mathrm{Aa}}$ & $8.5^{\mathrm{Aa}}$ \\
\hline Acidified distilled water & $8.5^{\mathrm{Aa}}$ & $8.4^{\mathrm{Aa}}$ & $8.4^{\mathrm{Aa}}$ & $8.3^{\mathrm{ABa}}$ & $8.1^{\text {Aa }}$ \\
\hline Distilled water & $8.5^{\mathrm{Aa}}$ & $8.4^{\mathrm{Aab}}$ & $8.3^{\mathrm{Aab}}$ & $7.9^{\mathrm{Bb}}$ & $7.9^{\mathrm{Ab}}$ \\
\hline \multicolumn{6}{|c|}{ Mouth feel } \\
\hline Acidified methanol & $8.1^{\mathrm{Aa}}$ & $7.5^{\mathrm{Bb}}$ & $8.0^{\mathrm{Aa}}$ & $8.1^{\mathrm{Aa}}$ & $8.4^{\mathrm{Aa}}$ \\
\hline Acidified ethanol & $8.1^{\mathrm{Aa}}$ & $7.6^{\mathrm{Bb}}$ & $8.1^{\mathrm{Aa}}$ & $8.2^{\mathrm{Aa}}$ & $8.2^{\mathrm{Aa}}$ \\
\hline Acidified distilled water & $8.1^{\mathrm{Aa}}$ & $8.2^{\mathrm{Aa}}$ & $8.1^{\mathrm{Aa}}$ & $8.2^{\mathrm{Aa}}$ & $8.0^{\mathrm{Aa}}$ \\
\hline Distilled water & $8.1^{\mathrm{Aa}}$ & $7.4^{\mathrm{Bb}}$ & $8.1^{\mathrm{Aa}}$ & $8.2^{\mathrm{Aa}}$ & $8.2^{\mathrm{Aa}}$ \\
\hline \multicolumn{6}{|c|}{ Overall acceptability } \\
\hline Acidified methanol & $8.5^{\mathrm{Ab}}$ & $7.7^{\mathrm{Bc}}$ & $8.6^{\mathrm{A} a b}$ & $8.7^{\text {Aab }}$ & $8.9^{\mathrm{Aa}}$ \\
\hline Acidified ethanol & $8.5^{\mathrm{Aa}}$ & $7.7^{\mathrm{Bb}}$ & $8.4^{\mathrm{Aa}}$ & $8.5^{\mathrm{Aa}}$ & $8.7^{\mathrm{Aa}}$ \\
\hline Acidified distilled water & $8.5^{\mathrm{Aab}}$ & $8.3^{\mathrm{Ab}}$ & $8.2^{\text {Aab }}$ & $8.5^{\mathrm{Aa}}$ & $7.9^{\mathrm{Bb}}$ \\
\hline Distilled water & $8.5^{\mathrm{Aa}}$ & $7.7^{\mathrm{Bb}}$ & $8.5^{\mathrm{Aa}}$ & $8.5^{\mathrm{Aa}}$ & $8.1^{\mathrm{Bab}}$ \\
\hline
\end{tabular}

Means values in same column showed the same superscript capital letters are not significantly different $(\mathrm{P} \geq 0.05)$

Means values in same raw showed the same superscript small letters are not significantly different $(\mathrm{P} \geq 0.05)$ 
Effect of Different Extraction Methods on Stablity of Anthocyanins Extracted from Red Onion peels (Allium cepa) and Its Uses as Food Colorants

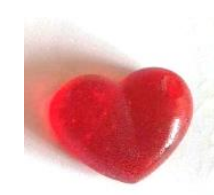

Synthetic color

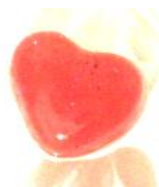

$0.15 \%$

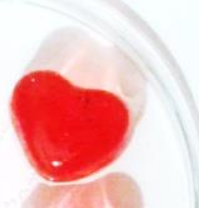

$0.30 \%$

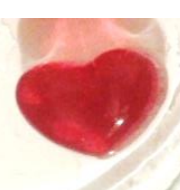

$0.2 \%$

$0.25 \%$

Acidified methanol

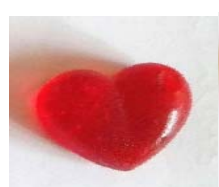

Synthetic color
$0.15 \%$

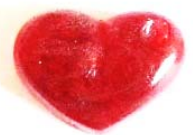

$0.30 \%$

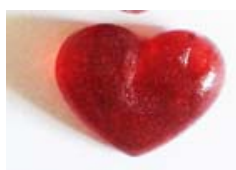

$0.2 \%$

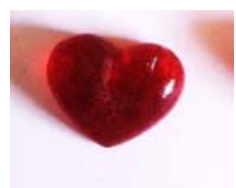

$0.25 \%$

Acidified ethanol

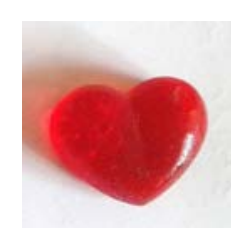

Synthetic color

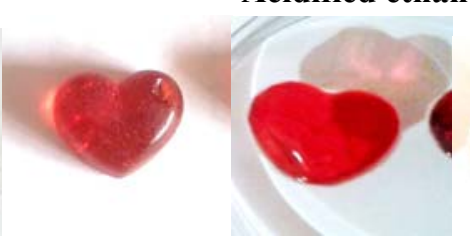

$0.30 \%$

$0.25 \%$
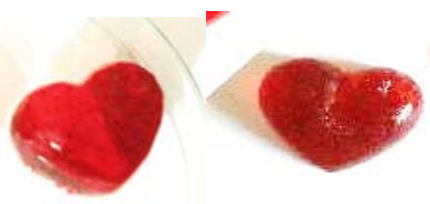

$0.15 \%$

$0.2 \%$

Distilled water Hcl
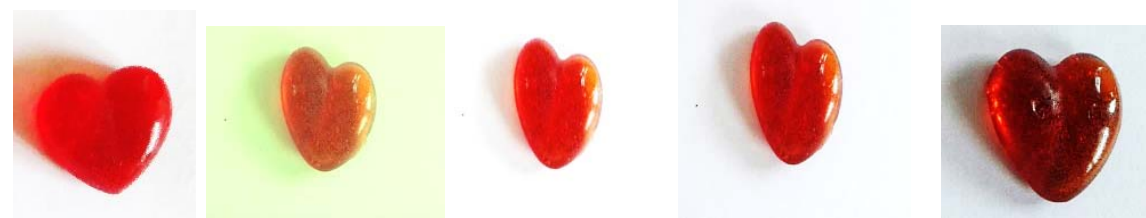

Synthetic color

$0.15 \%$

$0.2 \%$

$0.25 \%$

$0.30 \%$

Distilled water

Fig.(2): Hard candy prepared with deferent levels of anthocyanins were extracted from red onion peel by different solvents 
Effect of Different Extraction Methods on Stablity of Anthocyanins Extracted from Red

Onion peels (Allium cepa) and Its Uses as Food Colorants

Om-Hashem, A. A. Ali; Hanan, M.A.Al-sayed; Nessrien, M.N.Yasin and Effat, A.A. Afifi

Table (9): Means scores of sensory properties of glazing jelly prepared with different levels of anthocyanin extracted from onion peels by different solvents.

\begin{tabular}{|c|c|c|c|c|}
\hline \multicolumn{5}{|c|}{ Means scores of sensory properties } \\
\hline \multicolumn{5}{|c|}{ Color } \\
\hline Treatment & $\begin{array}{l}\text { Synthetic } \\
\text { color }\end{array}$ & $0.2 \%$ & $0.25 \%$ & $0.3 \%$ \\
\hline Acidified methanol & $8.6^{\mathrm{Aa}}$ & $8.1^{\mathrm{Ab}}$ & $8.7^{\mathrm{Aa}}$ & $8.4^{\mathrm{Aab}}$ \\
\hline Acidified ethanol & $8.6^{\mathrm{Aa}}$ & $7.7^{\mathrm{Ab}}$ & $8.5^{\mathrm{Aa}}$ & $8.3^{\mathrm{Aa}}$ \\
\hline Acidified distilled water & $8.6^{\mathrm{Aa}}$ & $7.8^{\mathrm{Ab}}$ & $8.4^{\mathrm{Aab}}$ & $8.1^{\mathrm{Aab}}$ \\
\hline distilled water & $8.6^{\mathrm{Aa}}$ & $8.1^{\mathrm{Aa}}$ & $8.6^{\mathrm{Aa}}$ & $8.5^{\mathrm{Aa}}$ \\
\hline \multicolumn{5}{|c|}{ Flavor } \\
\hline Acidified methanol & $8.8^{\mathrm{Aa}}$ & $8.9^{\mathrm{Aa}}$ & $8.6^{\mathrm{Aa}}$ & $7.7^{\mathrm{BCb}}$ \\
\hline Acidified ethanol & $8.8^{\mathrm{Aa}}$ & $8.8^{\mathrm{Aa}}$ & $7.8^{\mathrm{Bb}}$ & $7.2^{\mathrm{Cc}}$ \\
\hline Acidified distilled water & $8.8^{\mathrm{Aa}}$ & $8.6^{\mathrm{Aa}}$ & $8.5^{\mathrm{Aa}}$ & $8.2^{\mathrm{ABa}}$ \\
\hline distilled water & $8.8^{\mathrm{Aa}}$ & $8.7^{\mathrm{Aa}}$ & $8.6^{\mathrm{Aa}}$ & $8.6^{\mathrm{Aa}}$ \\
\hline \multicolumn{5}{|c|}{ Texture } \\
\hline Acidified methanol & $8.6^{\mathrm{Aa}}$ & $8.5^{\mathrm{Aa}}$ & $8.5^{\mathrm{Aa}}$ & $8.5^{\mathrm{Aa}}$ \\
\hline Acidified ethanol & $8.6^{\mathrm{Aa}}$ & $8.5^{\mathrm{Aa}}$ & $8.5^{\mathrm{Aa}}$ & $8.5^{\mathrm{Aa}}$ \\
\hline Acidified distilled water & $8.6^{\mathrm{Aa}}$ & $8.6^{\mathrm{Aa}}$ & $8.6^{\mathrm{Aa}}$ & $8.4^{\mathrm{Aa}}$ \\
\hline distilled water & $8.6^{\mathrm{Aa}}$ & $8.7^{\mathrm{Aa}}$ & $8.7^{\mathrm{ABa}}$ & $8.6^{\mathrm{Aa}}$ \\
\hline \multicolumn{5}{|c|}{ Clarity } \\
\hline Acidified methanol & $8.9^{\mathrm{Aa}}$ & $8.9^{\mathrm{Aa}}$ & $8.8^{\mathrm{Aab}}$ & $8.4^{\mathrm{Ab}}$ \\
\hline Acidified ethanol & $8.9^{\mathrm{Aa}}$ & $8.8^{\mathrm{Aa}}$ & $8.2^{\mathrm{Bb}}$ & $8.1^{\mathrm{Ab}}$ \\
\hline Acidified distilled water & $8.9^{\mathrm{Aa}}$ & $8.9^{\mathrm{Aa}}$ & $8.4^{\mathrm{ABab}}$ & $7.9^{\mathrm{Ab}}$ \\
\hline distilled water & $8.9^{\mathrm{Aa}}$ & $8.7^{\mathrm{Aa}}$ & $8.4^{\mathrm{ABab}}$ & $8.0^{\mathrm{Ab}}$ \\
\hline \multicolumn{5}{|c|}{ Grainess } \\
\hline Acidified methanol & $8.8^{\mathrm{Aa}}$ & $8.8^{\mathrm{Aa}}$ & $8.8^{\mathrm{Aa}}$ & $8.5^{\mathrm{Aa}}$ \\
\hline Acidified ethanol & $8.8^{\mathrm{Aa}}$ & $8.8^{\mathrm{Aa}}$ & $8.8^{\mathrm{Aa}}$ & $8.5^{\mathrm{Aa}}$ \\
\hline Acidified distilled water & $8.8^{\mathrm{Aa}}$ & $8.5^{\mathrm{Aa}}$ & $8.4^{\mathrm{Aa}}$ & $8.3^{\mathrm{Aa}}$ \\
\hline distilled water & $8.8^{\mathrm{Aa}}$ & $8.7^{\mathrm{Aa}}$ & $8.8^{\mathrm{Aa}}$ & $8.8^{\mathrm{Aa}}$ \\
\hline \multicolumn{5}{|c|}{ Overall acceptability } \\
\hline Acidified methanol & $8.9^{\mathrm{Aa}}$ & $8.8^{\mathrm{Aa}}$ & $8.7^{\mathrm{Aa}}$ & $8.0^{\mathrm{Bb}}$ \\
\hline Acidified ethanol & $8.9^{\mathrm{Aa}}$ & $8.6^{\mathrm{Aa}}$ & $8.5^{\mathrm{Aa}}$ & $7.6^{\mathrm{Bb}}$ \\
\hline Acidified distilled water & $8.9^{\mathrm{Aa}}$ & $8.4^{\mathrm{Aa}}$ & $8.8^{\mathrm{Aa}}$ & $8.6^{\text {Aa }}$ \\
\hline distilled water & $8.9^{\mathrm{Aa}}$ & $8.3^{\mathrm{Ab}}$ & $8.9^{\mathrm{Aa}}$ & $8.5^{\mathrm{Aab}}$ \\
\hline
\end{tabular}

Means values in same column showed the same superscript capital letters are not significantly different $(\mathrm{P} \geq 0.05)$

Means values in same raw showed the same superscript small letters are not significantly different $(\mathrm{P} \geq 0.05)$ 
Effect of Different Extraction Methods on Stablity of Anthocyanins Extracted from Red Onion peels (Allium cepa) and Its Uses as Food Colorants

Om-Hashem, A. A. Ali; Hanan, M.A.Al-sayed; Nessrien, M.N.Yasin and Effat, A.A. Afifi
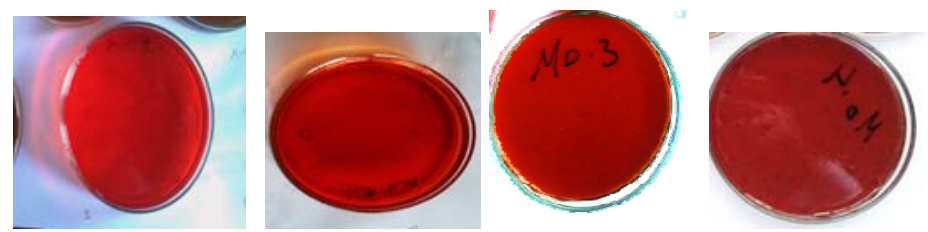

Synthetic color

$0.2 \%$

$0.25 \%$

$0.30 \%$

\section{Acidified methanol}
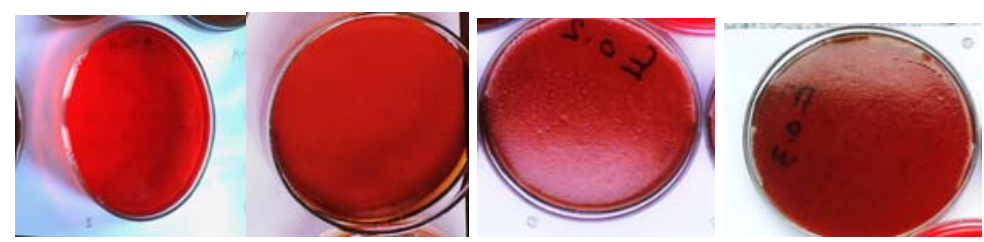

Synthetic color

$0.2 \%$

$0.25 \%$

$0.30 \%$

\section{Acidified ethanol}

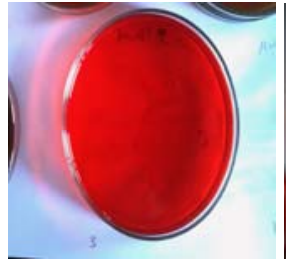

Synthetic color

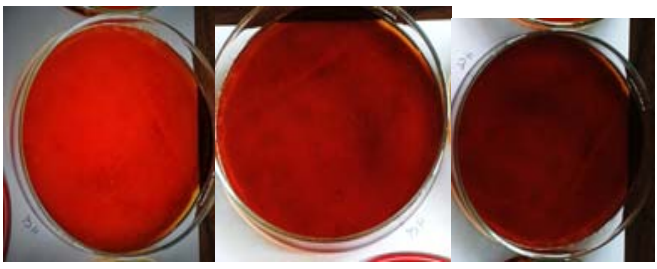

$0.2 \%$

$0.25 \%$

$0.30 \%$

Acidified Distilled water
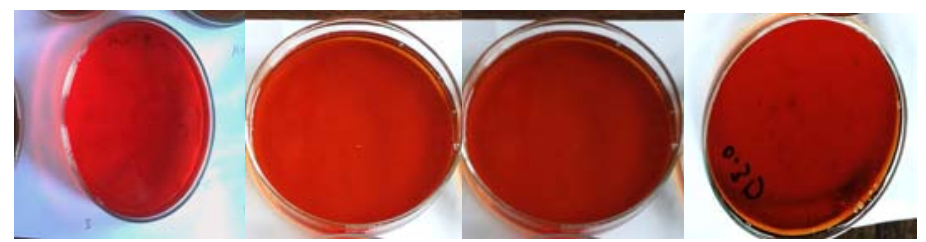

Synthetic color

$0.2 \%$

$0.25 \%$

$0.30 \%$

\section{Distilled water}

Fig.(3) : Glazing jelly prepared with deferent levels of anthocyanins were extracted from red onion peel by different solvent 
Effect of Different Extraction Methods on Stablity of Anthocyanins Extracted from Red Onion peels (Allium cepa) and Its Uses as Food Colorants

Om-Hashem, A. A. Ali; Hanan, M.A.Al-sayed; Nessrien, M.N.Yasin and Effat, A.A. Afifi

\section{تأثير طرق الإستخلاص المختلفة على ثبات الأنثوسياتين المستخلص من قشور البصل الأحمر وإستخدامه كملون كلأغَذِّة}

أم هاشم أحمد أمين،2حنان محمد عبده1، نسرين محمد نبيه12

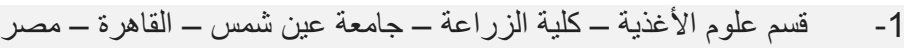

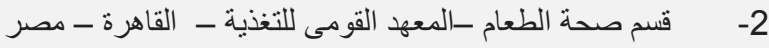

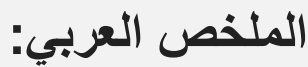

أجريت هذه الدراسة بهدف الحصول على صبغة الأنثوسيانين من قثور البصل

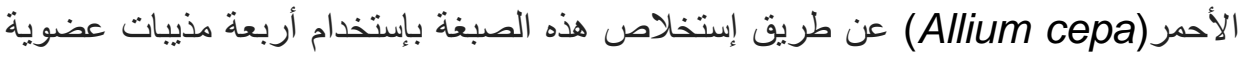

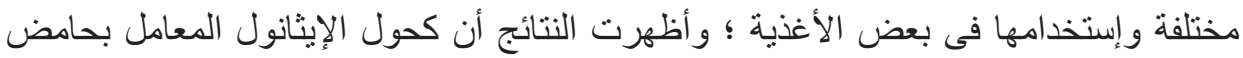

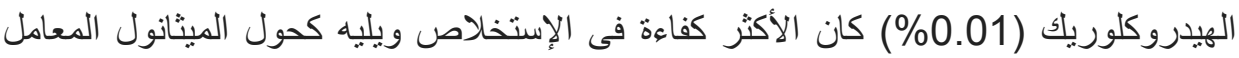

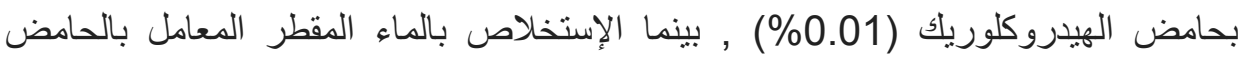

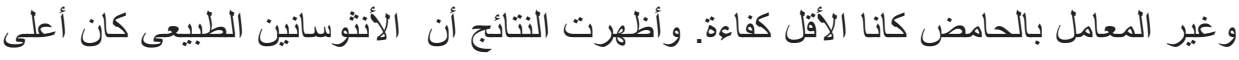

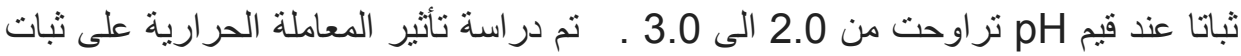

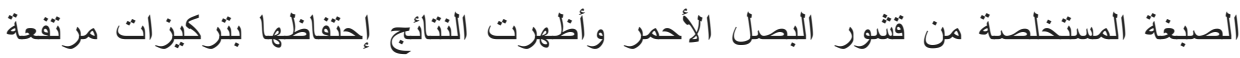
وصلت الى 99.16, 98.79 , 91.56, 69.45 \% للصبغة المستخلصة بكحول الميثانول المعامل بحامض الهيدروكلوريك بينما كانت 98.15, 99.15 \% 98.01, 86.68, 66.22\% للصبغة

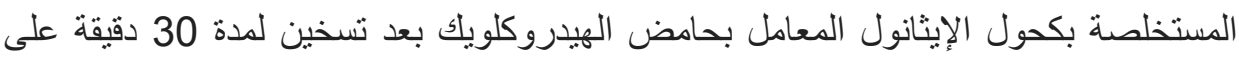

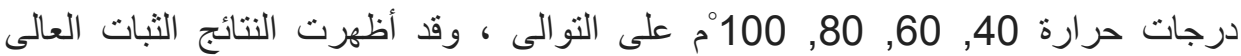

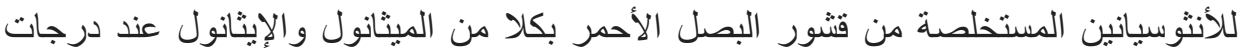

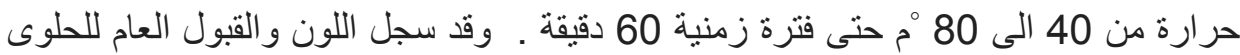

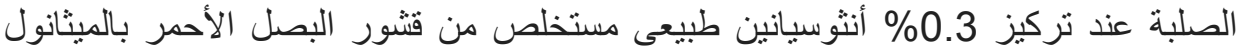

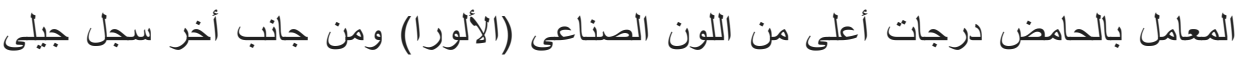
التغطية عند تركيز 0.25\% أنثوسيانين طبيعى مستخلص من قشتور البصل الأحمر بالمذيبات

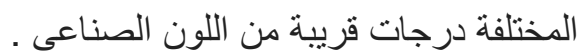

الكلمات المفتاحية: قثور البصل الاحمر، الوان طبيعيه، الانثوسانين ، استخلاصه، ثباته، استخدامه 